\title{
Comparison between Oncotype DX test and standard prognostic criteria in estrogen receptor positive early-stage breast cancer
}

\author{
Comparação entre o teste Oncotype DX e critérios prognósticos padronizados \\ em câncer de mama receptor de estrogênio positivo em estágio inicial
}

\author{
Marcelo Roberto Pereira Freitas ${ }^{1}$, Sergio Daniel Simon ${ }^{2}$
}

\begin{abstract}
Objective: To compare the prognosis estimated by standard prognostic criteria versus the prognosis estimated by the Oncotype DX. Methods: A retrospective study was performed on 22 patients with positive estrogen receptor, early-stage breast cancer who had an Oncotype DX recurrence score available. Results: Kappa value between Oncotype DX and standard prognostic criteria was: Adjuvant! ( $\mathrm{K}=0.091)$, Adjuvant! (Transbig) $(\mathrm{K}=0.182)$ and National Comprehensive Cancer Network ( $K=0.091)$. The Fisher's exact test did not show correlation between Oncotype and standard prognostic criteria. Conclusion: Standard prognostic criteria showed no correlation with Oncotype DX.
\end{abstract}

Keywords: Breast neoplasms/diagnosis; Gene expression profiling

\section{RESUMO}

Objetivo: Comparar o prognóstico estimado por critérios prognósticos padronizados e o prognóstico estimado pelo Oncotype DX. Métodos: Foi realizado um estudo retrospectivo envolvendo 22 pacientes com receptor de estrogênio positivo, portadoras de câncer de mama em estágio inicial que possuíam uma pontuação disponível avaliada pelo teste Oncotype DX. Resultados: 0 valor Kappa entre o teste Oncotype DX e os critérios prognósticos padrão foi: Adjuvant! ( $K=0,091)$, Adjuvant! (Transbig) $(K=0,182)$ e National Comprehensive Cancer Network ( $\mathrm{K}=0,091)$. 0 teste exato de Fisher não mostrou correlação entre Oncotype DXe os critérios prognósticos padronizados. Conclusão: Os critérios prognósticos padronizados não mostraram correlação com o teste Oncotype DX.

Descritores: Neoplasias da mama/diagnóstico; Perfilação de expressão gênica

\section{INTRODUCTION}

In developed countries, approximately $65 \%$ of women with invasive breast cancer have negative lymph node disease upon diagnosis, and $85 \%$ of these women are expected to be alive and free from distant metastasis at 10 years $^{(1,2)}$. Chemotherapy in this group of patients, especially among patients with estrogen receptorpositive disease treated with adjuvant hormone therapy, offers only a modest improvement in 10 -year survival $^{(2-4)}$.

However, most patients with small tumors and negative axillary status, have indication for adjuvant chemotherapy ${ }^{(5,6)}$. Current clinical guidelines have conflicting criteria for the selection of patients who will not benefit from chemotherapy. This is largely due to our limited ability to identify individual patients who are unlikely to benefit from such treatment. Consequently, chemotherapy is offered to a large group of patients that could be cured with loco-regional treatment and endocrine therapy only. More accurate methods of risk assessment could avoid the toxicity of chemotherapy for these patients ${ }^{(7)}$.

Currently, the indication for adjuvant systemic therapy takes into account the risk of disease recurrence, the estimated benefit of adjuvant therapy, the toxicity of treatment and the comorbidities. Conventional risk classifiers include the National Comprehensive Cancer Network guidelines (NCCN), the St. Gallen consensus recommendations, and Adjuvant! Online. These classifiers estimate recurrence risk by considering some

\footnotetext{
Study carried out at Hospital Israelita Albert Einstein - HIAE, São Paulo (SP), Brazil; Centro Paulista de Oncologia - CPO, São Paulo (SP), Brazil; Centro de Hematologia, Oncologia e Transplante de Medula Óssea - Porto Alegre (RS), Brazil.

1 Universidade Federal de São Paulo - UNIFESP, São Paulo (SP), Brazil.

${ }^{2}$ Hospital Israelita Albert Einstein - HIAE, São Paulo (SP), Brazil; Centro Paulista de Oncologia - CPO, São Paulo (SP), Brazil.

Corresponding author: Marcelo Roberto Pereira Freitas - Laboratório de Biologia Molecular do Câncer - Rua Pedro de Toledo, 669, $11^{\circ}$ andar - Vila Clementino - CEP 04039-020 - São Paulo (SP), Brasil Tel.: 11 5539-6151 - E-mail: docfreitas@gmail.com

Received on: Apr 8, 2011 - Accepted on: Jun 27, 2011

Conflict of interest: none
} 
criteria, such as clinical and histological characteristics. Clinical trial data and physician experience support the development and regular updates of these classifiers and studies showed significant predictive ability ${ }^{(8)}$.

The St. Gallen expert consensus defines three recurrence risk categories. The low risk group includes patients with tumors with all of the following characteristics: node negative axilla, $\mathrm{pT}<2 \mathrm{~cm}$, grade 1 , no vascular invasion, positive estrogen receptor (ER) or progesterone receptor (PgR), HER2 negative status and age $>35$ years. The intermediate risk group refers to patients with node negative axilla and at least one of the following features: pT $>2 \mathrm{~cm}$, grade 2 or 3 , vascular invasion, positive HER2 status, negative ER and $\mathrm{PgR}$, age $<35$ years or patients with 1-3 nodes positive and positive ER and/or PgR and negative HER2 status. The high risk group includes patients with 1-3 positive nodes and negative ER and $\mathrm{PgR}$ or positive HER2 status, or $>4$ positive nodes. There is no indication for adjuvant chemotherapy for the low risk group and this modality of treatment should always be indicated in the high risk group ${ }^{(9,10)}$.

The NCCNrecommendations excludechemotherapy for patients with well-differentiated tumors up to $1 \mathrm{~cm}$ and no unfavorable characteristics. For those with lymph node-negative, hormone receptor-positive breast cancer tumors greater than $1 \mathrm{~cm}$, endocrine therapy with chemotherapy is recommended (category 1$)^{(11)}$.

Adjuvant! is a computer program that estimates the risk of recurrence and mortality for each individual patient, providing also estimates of the benefits offered by each proposed modality of adjuvant therapy. This program is based in projections. Because of the multiplicity of sources of error and the uncertainty of their interactions, the program does not calculate a $95 \%$ confidence interval for its estimates ${ }^{(12,13)}$. Adjuvant! was validated using the tumor registry of the province of British Columbia, Canada. The outcomes obtained with the current follow-up of 4,083 women with T1-2, N0-1, $\mathrm{M} 0$ breast cancer were compared with predicted 10 -year overall survival (OS) and event-free survival (EFS) for each patient. The OS and EFS estimated by Adjuvant! were 71.7 and $71 \%$ and the observed outcomes were 72 and $70,1 \%$, respectively. Adjuvant! is being constantly improved and updated with the publication of new clinical trials, and is currently in its version $8.0^{(14)}$.

Recently, gene expression analysis in breast cancer emerged as a tool able to refine the prognosis and individualize the recommendations for adjuvant systemic treatment. Oncotype DX uses a reversetranscriptase polymerase chain reaction to quantify the expression of specific mRNA for 16 cancer genes and 5 reference genes that were selected on the basis of their predictive and prognostic value, in patients with lymph node negative and positive estrogen receptor, treated with tamoxifen. The result of the test is expressed in a recurrence score (RS).

Expression levels of these genes are used to classify patients into the following categories: low risk $(\mathrm{RS}<18)$, intermediate risk ( $\mathrm{RS}>18$ and $<31$ ), and high risk (RS $>31$ ). The estimates of the rates of distant recurrence at 10 years in the low-risk, intermediate-risk, and high-risk groups were $6.8 \%$ (95\% CI: 4.0-9.6), $14.3 \%$ (95\% CI: 8.320.3 ), and $30.5 \%$ (95\% CI: 23.6-37.4), respectively ${ }^{(15)}$.

Another important utility of Oncotype DX is its ability to predict benefit from adjuvant chemotherapy. The 21-gene assay was performed in a subset of 651 patients from the B-20 trial, which randomized women with ER-positive, lymph node-negative breast cancer to receive tamoxifen for 5 years either alone or plus MF or CMF chemotherapy (M: methotrexate, F: fluorouracil and $\mathrm{C}$ : cyclophosphamide). The test for interaction between chemotherapy treatment and RS was statistically significant. Patients with high RS had a large benefit from chemotherapy, while patients with low RS tumors derived minimal, if any, benefit from chemotherapy. Patients with intermediate-RS tumors did not appear to derive a large benefit, but the uncertainty in the estimate cannot exclude a clinically important benefit ${ }^{(16)}$.

Similar findings have been reported in another trial comparing tamoxifen with tamoxifen plus cyclophosphamide, doxorubicin, and fluorouracil chemotherapy in postmenopausal women with nodepositive and hormone receptor-positive breast cancer ${ }^{(17)}$.

Although performed retrospectively, the validation of Oncotype DX using a prospectively collected clinical trial data set, but retrospectively collected tissues from the data set, might be considered as level of evidence I for use of this assay. The American Society of Clinical Oncology recommendations for the use of tumor markers in breast cancer states that Oncotype DX assay can be used to predict the risk of recurrence in patients treated with tamoxifen, and used to identify patients who are predicted to obtain the most therapeutic benefit from adjuvant tamoxifen and may not require adjuvant chemotherapy. There are insufficient data at present to comment on whether these conclusions can be applied to hormonal therapies other than tamoxifen, or whether this assay applies to other chemotherapy regimens ${ }^{(18)}$. All recommendations involving the use of RS in treatment decision-making are categorized as level of evidence $2 \mathrm{~B}^{(11)}$.

\section{OBJECTIVE}

The purpose of this study was to compare the prognosis estimated by standard prognostic criteria and by the Oncotype DX test. 


\section{METHODS}

\section{Patients}

This study was performed with clinical data from patients seen at three Brazilian Medical Centers: Hospital Israelita Albert Einstein and Centro Paulista de Oncologia, in São Paulo (SP); and Centro de Hematologia, Oncologia e Transplante de Medula Óssea, in Porto Alegre (RS). The Research Ethics Committee of the Hospital Israelita Albert Einstein approved the protocol (0215.0.028.000-08) and all patients gave written informed consent to participate of the study.

Patients were eligible for inclusion if they were estrogen receptor positive; early-stage breast cancer, diagnosed between 2006 and 2008, and had an Oncotype DX recurrence score available. Twenty-two patients were included in this retrospective study.

\section{Methods}

Comparison with the recurrence risk estimated by Oncotype DX was made with the risk classification of the NCCN (low and high) and St. Gallen's criteria (low, intermediated and high).

For comparison with Adjuvant! (version 8.0) two strategies were used: a) the value obtained with risk percentile to recurrence in 10 years with the reduction of the effects of five years of tamoxifen, predicted by Adjuvant!, was transformed into risk groups (low, intermediated and high), using the plot of distant recurrence of Oncotype DX; b) using Transbig consortium criteria that define the low clinical risk group and include patients with a 10 -year breast cancer survival probability of at least $88 \%$, if their tumors were positive in more than $1 \%$ of the cases for expression of ER, considering the use of five years of tamoxifen.

\section{Statistical analyses}

Fisher's exact test and Kappa test for concordance were used for comparisons between groups.

\section{RESULTS}

The median age of the patients was 52.9 years (range: 39 to 79 years). All patients had positive ER and negative HER2 breast cancer. Nineteen patients $(86 \%)$ had tumors with $<2 \mathrm{~cm}, 18(82 \%)$ patients had no axillary involvement and four patients had positive nodes (two cases of micro-metastasis and two cases of macro-metastasis). The proportion of patients with histological grade tumors 1, 2 and 3 was 9, 68, 23\%, respectively.
The St. Gallen and NCCN criteria classify few patients in the low risk group. Using Transbig criteria to classify patients in risk categories predicted by Adjuvant! more patients were identified at low risk of using risk percentile (Table 1).

Standard prognostic criteria showed no correlation with Oncotype DX (Table 2), that was corroborated with the results of the Kappa coefficient. The value Kappa between Oncotype DX and Adjuvant! was $(\mathrm{K}=0.091)$, Adjuvant! (Transbig) $(\mathrm{K}=0.182)$ and $\mathrm{NCCN}$ $(\mathrm{K}=0.091)$.

Table 1. Distribution of patients in each risk category

\begin{tabular}{lccccc}
\hline Risk category & $\begin{array}{c}\text { Oncotype } \\
\text { DX }\end{array}$ & $\begin{array}{c}\text { Adjuvant! } \\
\text { (risk } \\
\text { percentile) }\end{array}$ & $\begin{array}{c}\text { Adjuvant! } \\
\text { (Transbig) }\end{array}$ & St. Gallen & NCCN \\
\hline Low & 50 & 13.6 & 63.6 & 0 & 4.5 \\
Intermediate/high & 50 & 86.4 & 36.4 & 100 & 95.5 \\
\hline Values expressed in \%. \\
NCCN: National Comprehensive Cancer Network.
\end{tabular}

Table 2. Comparison between Oncotype DX and standard prognostic criteria

\begin{tabular}{lccc}
\hline \multicolumn{3}{c}{ Oncotype DX } \\
\hline & Low & Intermediate/high & p-value \\
\hline Adjuvant! & 1 & 2 & \\
Low & 10 & 9 & 1.0 \\
Intermediate/high & & & \\
Adjuvant! (Transbig) & 8 & 6 & 0.659 \\
Low & 3 & 5 & \\
Intermediate/high & & & 1.0 \\
NCCN & 1 & 0 & \\
Low & 10 & 11 & \\
Intermediate/high & & & \\
\hline
\end{tabular}

NCCN: National Comprehensive Cancer Network.

\section{DISCUSSION}

Oncotype DX reclassified the risk group of a substantial number of patients, showing that conventional risk classifiers do not correlate well with gene expression analysis. The reclassification demonstrates the important impact of Oncotype DX, since the change of patients from high to low risk category reduces the number of patients who could undergo unnecessary chemotherapy.

This was more expressive using the NCCN and St. Gallen criteria, as these classified almost all patients as intermediate or high risk groups. Oncotype DX reclassified $50 \%$ of patients to the low risk category. Similar data were presented by Paik et al., in which $92.1 \%$ of 668 patients enrolled in the NSABP B-14 trial were considered as intermediate or high risk by NCCN and St. Gallen, with $50.6 \%$ of patients being classified as low risk by Oncotype DX ${ }^{(19)}$. 
The inability of the St. Gallen criteria to identify patients at low risk was also demonstrated in a study that compared the 70-gene signature test (another test of gene expression analysis) with the St. Gallen criteria. The 70 -gene signature leads to a 20 to $30 \%$ reduction in the number of women who would otherwise receive chemotherapy $^{(8)}$.

The use of percentile values for comparison between Oncotype DX and Adjuvant! recurrence risk showed no correlation and few patients were classified as low risk. One reason is that the Oncotype DX recurrence estimates are for distant recurrence only (risk of metastatic disease), while the recurrence estimate given by Adjuvant! is for all causes of recurrence (local, regional, contralateral breast cancer, and distant recurrence). Thus Adjuvant!'s estimates of risk of recurrence are usually higher than those of the Oncotype DX test ${ }^{(13)}$. However, it has been demonstrated that there is an association between Oncotype DX and risk of local or regional recurrence ${ }^{(20)}$.

Because the risk of distant recurrence is closely linked to the risk of death by breast cancer, the most appropriate comparisons are between the risk of breast cancer mortality, as estimated by Adjuvant!, and the risk of distant recurrence, as given by the Oncotype DX test ${ }^{(13)}$. However, when the patients were classified in risk groups using overall survival probabilities calculated by Adjuvant!, the absence of correlation remained.

The comparison between Adjuvant! and gene signatures assay was performed in three studies, showing that gene expression tests are a more accurate predictor of relapse and overall survival, and that combining it with conventional predictors yields more information $^{(8,21-23)}$.

Standard prognostic criteria have qualitative or subjective components that add variability to risk estimates. Moreover, differences among criteria or their use in different classifiers may result in significantly different risk estimates for the same patients.

\section{CONCLUSION}

Standard prognostic criteria showed no correlation with Oncotype DX.

\section{ACKNOWLEDGMENTS}

The authors thank Dr. Carlos Henrique Escosteguy Barrios, Dr. Oren Smaletz and Dr. René Gansl for their cooperation in referring patients.

\section{REFERENCES}

1. Ghafoor A, Jemal A, Ward E, Cokkinides V, Smith R, Thun M. Trends in breast cancer by race and ethnicity. CA Cancer J Clin. 2003;53(6):342-55.

2. Fisher B, Jeong JH, Bryant J, Anderson S, Dignam J, Fisher ER, Wolmark N; National Surgical Adjuvant Breast and Bowel Project randomised clinical trials. Treatment of lymph-nodenegative, oestrogen-receptor-positive breast cancer: longterm findings from National Surgical Adjuvant Breast and Bowel Project randomised clinical trials. Lancet. 2004;364(9437):858-68.

3. Polychemotherapy for early breast cancer: an overview of the randomised trials. Early Breast Cancer Trialists Collaborative Group. Lancet. 1998;352(9132):930-42.

4. Berry DA, Cirrincione C, Henderson IC, Citron ML, Budman DR, Goldstein LJ, et al. Estrogen-receptor status and outcomes of modern chemotherapy for patients with node-positive breast cancer. JAMA. 2006;295(14):1658-67.

5. Fisher B, Dignam J, Tan-Chiu E, Anderson S, Fisher ER, Wittliff JL, et al. Prognosis and Treatment of Patients with Breast Tumors of One Centimeter or Less and Negative Axillary Lymph Nodes. J Natl Cancer Inst. 2001;93(2):112-20.

6. Baum M, Ravdin PM. Decision-making in early breast cancer guidelines and decision tools. Eur J Cancer. 2002;38(6):745-9.

7. Habel LA, Shak S, Jacobs MK, Capra A, Alexander C, Pho M, et al. A populationbased study of tumor gene expression and risk of breast cancer death among lymph node-negative patients. Breast Cancer Res. 2006;8(3):R25.

8. Marchionni L, Wilson RF, Wolff AC, Marinopoulos S, Parmigiani G, Bass EB, et al. Systematic review: gene expression profiling assays in early-stage breast cancer. Ann Intern Med. 2008;148(5):358-69.

9. Goldhirsch A, Glick JH, Gelber RD, Coates AS, Thürlimann B, Senn HJ, et al. Meeting highlights: international expert consensus on the primary therapy of early breast cancer 2005. Ann Oncol 2005;16(10):1569-83.

10. Goldhirsch A, Wood WC, Gelber RD, Coates AS, Thürlimann B, Senn HJ; 10th St. Gallen conference. Progress and promise: highlights of the international expert consensus on the primary therapy of early breast cancer 2007. Ann Oncol 2007;18(7):1133-44.

11. National Comprehensive Cancer Network. Clinical practice guidelines in oncology - breast cancer. NCCN; 2008. v.2.

12. Ravdin PM, Siminoff LA, Davis GJ, Mercer MB, Hewlett J, Gerson N, et al. Computer program to assist in making decisions about adjuvant therapy for women with early breast cancer. J Clin Oncol. 2001;19(4):980-91.

13. Adjuvant Program[Internet]. [cited 2011 Sep 14]. Available from : http://www. adjuvantonline.com

14. Olivotto IA, Bajdik CD, Ravdin PM, Speers CH, Coldman AJ, Norris BD, et al. Population-Based Validation of the Prognostic Model ADJUVANT for Early Breast Cancer. J Clin Oncol 2005;23(12):2716-25.

15. Paik S, Shak S, Tang G, Kim C, Baker J, Cronin M, et al. A multigene assay to predict recurrence of tamoxifen-treated, node-negative breast cancer. N Engl J Med. 2004;351(27):2817-26.

16. Paik S, Tang G, Shak S, Kim C, Baker J, Kim W, et al. Gene expression and benefit of chemotherapy in women with node-negative, estrogen receptorpositive breast cancer. J Clin Oncol. 2006;24(23):3726-34.

17. Albain K, Barlow W, Shak S, Hortobagyi G, Livingston R Yeh I, et al. Prognostic and predictive value of the 21-gene recurrence score assay in postmenopausal, node-positive, ER-positive breast cancer. 30th Annual San Antonio Breast Cancer Symposium 2007; Dec 13-16. San Antonio, TX: abstract 10 .

18. Harris L, Fritsche H, Mennel R, Norton L, Ravdin P, Taube S, Somerfield MR, Hayes DF, Bast RC Jr; American Society of Clinical Oncology. American Society of Clinical Oncology 2007 update of recommendations for the use of tumor markers in breast cancer. J Clin Oncol. 2007;25(33):5287-312. 
19. Paik S, Shak S, Tang G, Kim C, Kim W, Baker J, et al. Risk classification of breast cancer patients by the recurrence score assay: comparison to guidelines based on patient age, tumor size, and tumor grade. Breast Cancer Res Treat. 2004;88 (Suppl. 1):S21.

20. Mamounas E, Tang G, Bryant J, et al. Association between the 21-gene recurrence score assay (RS) and risk of loco-regional failure in nodenegative, ER-positive breast cancer: Results from NSABP B-14 and NSABP B-20. Breast Cancer Res Treat. 2005; 94:S16:

21. Goldstein LJ, Gray R, Badve S, Childs BH, Yoshizawa C, Rowley S, et al. Prognostic utility of the 21-gene assay in hormone receptor-positive operable breast cancer compared with classical clinicopathologic features. J Clin Oncol. 2008;26(25):4063-71.

22. Buyse M, Loi S, van't Veer L, Viale G, Delorenzi M, Glas AM, et al. Validation and clinical utility of a 70-gene prognostic signature for women with nodenegative breast cancer. J Natl Cancer Inst. 2006;98(17):1183-92.

23. Bryant J. Toward a more rational selection of tailored adjuvant therapy. 9th International St. Gallen Oncology Conference on Primary Therapy of Early Breast Cancer 2005. St. Gallen, Switzerland; 2005. 